\title{
Uji Total Bakteri Susu Segar Kambing Jawa Randu di Siliragung, Banyuwangi
}

\section{Total Plate Count of Bacteria on Jawa Randu's Fresh Milk in Siliragung, Banyuwangi}

\author{
Elga Rastika Virya Nanda ${ }^{1 *}$, Nenny Harijani ${ }^{2}$, Prima Ayu Wibawati ${ }^{3}$ \\ ${ }^{1}$ Mahasiswa, ${ }^{2}$ Departemen Kesehatan Masyarakat Veteriner, \\ Fakultas Kedokteran Hewan, Universitas Airlangga \\ *Corresponding author: elga.rastika.virya-2015@fkh.unair.ac.id
}

\begin{abstract}
Abstrak
Penelitian bertujuan untuk mengetahui total bakteri susu segar kambing Jawa Randu di Kecamatan Siliragung, Kabupaten Banyuwangi. Sampel susu segar diambil dari botol penampung susu menggunakan $10 \mathrm{ml}$ pipet. Pengujian Total Plate Count dilakukan secara duplo. Hasil perhitungan menunjukkan rata-rata cemaran bakteri pada masing-masing peternakan adalah $2.5 \times 10^{5} \mathrm{CFU} / \mathrm{ml}, 2.2 \times 10^{5} \mathrm{CFU} / \mathrm{ml}, 8.3 \times 10^{5} \mathrm{CFU} / \mathrm{ml}$ dan 8.5 x $10^{5} \mathrm{CFU} / \mathrm{ml}$. Dari hasil tersebut dapat disimpulkan bahwa total bakteri susu segar kambing Jawa Randu di Siliragung, Banyuwangi masih belum sesuai standar.
\end{abstract}

Kata kunci: susu segar, kambing Jawa Randu, Total Plate Count

\section{Abstract}

This study aimed to measure total bacteria on Jawa Randu's fresh milk in Siliragung, Banyuwangi using Total Plate Count Test. Milk samples was taken from four Jawa Randu farms in Siliragung, Banyuwangi. The samples of fresh milk was taken from the milk container bottle using $10 \mathrm{ml}$ glass pipette. The samples were stored in the cooler box and then analyzed. TPC testing was conducted in Duplo. The results showed that the average bacterial contamination in each of the farms were $2.5 \times 10^{5} \mathrm{CFU} / \mathrm{ml}, 2.2 \times 10^{5} \mathrm{CFU} / \mathrm{ml}, 8.3 \times 10^{5}$ CFU/ml and $8.5 \times 10^{5} \mathrm{CFU} / \mathrm{ml}$. It can be concluded that the quality of Jawa Randu fresh milk in Siliragung Banyuwangi was still not suitable with standard.

Keywords: fresh milk, Jawa Randu goat, Total Plate Count

Received: 30 Oktober 2019

Revised: 15 November 2019

Accepted: 23 April 2020

\section{PENDAHULUAN}

Kebutuhan susu di Indonesia semakin meningkat seiring dengan kesadaran masyarakat akan pentingnya nutrisi dari susu. Susu merupakan bahan pangan asal hewan yang memiliki nilai gizi tinggi dan lengkap yang dibutuhkan oleh tubuh. Menurut Hasim dan Martindah (2012), di dalam susu mengandung vitamin yang larut dalam lemak yaitu vitamin A, D, E dan K. Susu mengandung berbagai macam tipe protein, yang dapat dikelompokkan menjadi 2 macam, yaitu kasein (80\%) dan laktoglobulin (20\%). Menurut Griffiths (2000), susu mempunyai kandungan protein dan lemak yang tinggi dibandingkan dengan makanan lain. Komponen yang ada dalam susu antara lain air, lemak, protein, laktosa dan mineral serta vitamin dalam perbandingan seimbang. Terdapat beberapa jenis ternak yang menjadi penghasil susu, contohnya adalah kambing perah. Saat ini telah banyak dikembangkan peternakan kambing perah di Kabupaten Banyuwangi, salah satunya ada di Kecamatan Siliragung.

Kecamatan Siliragung terletak di bagian selatan dari Kabupaten Banyuwangi. Ada empat peternakan kambing perah di Kecamatan Siliragung dengan jenis kambing perah Jawa Randu. Kambing Jawa Randu ini merupakan kambing perah yang paling banyak dikembangkan di Kecamatan Siliragung, karena manajemen pemeliharaannya yang mudah. Susu segar kambing sudah banyak dikonsumsi masyarakat di Kecamatan Siliragung Kabupaten 
Banyuwangi, namun belum ada penelitian tentang jumlah bakteri yang mencemari susu segar tersebut.

Menurut Ceballos et al., (2009), susu kambing mempunyai khasiat yang lebih banyak dibandingkan dengan susu sapi. Hal tersebut disebabkan susu kambing mempunyai butir lemak yang lebih kecil dibandingkan susu sapi, dan proporsi asam lemak rantai pendek yang relatif banyak sehingga mudah dicerna. Komponen protein susu kambing hampir sama dengan susu sapi, namun komposisi kaseinnya berbeda. Susu sapi mengandung 55\% alpha kasein, $30 \%$ beta kasein dan $15 \%$ kasein, sedangkan susu kambing mengandung 19\% alpha S-1 kasein, $21 \%$ alpha S-2 kasein dan $60 \%$ beta kasein (LPPM IPB, 2009). Nilai gizi yang tinggi menyebabkan susu menjadi media yang baik untuk pertumbuhan dan perkembangan bakteri, sehingga dalam waktu yang singkat susu menjadi tidak layak untuk dikonsumsi bila tidak ditangani dengan baik (Mennane et al., 2007).

Bakteri yang berkembang dalam susu selain menyebabkan susu menjadi rusak, juga dapat membahayakan kesehatan manusia sebagai konsumen. Pertumbuhan bakteri dalam susu dapat menurunkan mutu dan keamanan susu, yang ditandai oleh perubahan rasa, aroma, warna, konsistensi dan tampilan. Jumlah bakteri dalam susu dapat digunakan sebagai bahan pertimbangan untuk menjamin konsumen menerima susu berkualitas. Bakteri dalam susu dapat digunakan sebagai indikator pencemaran dan kualitas sanitasi. Jenis bakteri seperti Escherichia coli, Enterobacteriaceae dan Streptobacillus telah lama dianggap sebagai bakteri indikator mutu (Chotiah, 2008). Berdasarkan uraian di atas maka perlu dilakukan pengujian untuk mengetahui jumlah total cemaran bakteri Total Plate Count (TPC) susu segar kambing Jawa Randu di Kecamatan Siliragung.

\section{METODE PENELITIAN}

Rancangan penelitian yang dilakukan menggunakan metode deskriptif, yaitu menghitung jumlah bakteri pada susu segar kambing yang diuji menggunakan metode TPC. Pengambilan sampel susu kambing segar dilakukan di semua peternakan kambing perah Jawa Randu di Siliragung Banyuwangi. Jumlah sampel yang diambil pada penelitian ini semua sampel pada botol air untuk menampung susu segar yang ada pada semua peternakan dengan 2 kali pengujian (duplo). Penelitian ini menggunakan 20 sampel yang diambil dari 4 peternakan kambing perah Jawa Randu dengan jumlah sampel dari masing-masing peternakan adalah 5 sampel.Penelitian dilakukan di Laboratorium Unit Pelaksana Teknis (UPT) Pengujian Mutu dan Pengembangan Produk Kelautan dan Perikanan (PMP2KP) Banyuwangi.

Penelitian ini menggunakan metode tuang TPC BSN 2332.3:2015 cara pembuatan media Plate Count Agar Plate Count Agar (PCA) ;Tryptone (5 g), Yeast extract (22,5 g, Dextrose (1 g), agar (15 g), aquades (1 L) dicampurkan dalam erlemeyer dan panaskan bahan hingga mendidih. Kemudian sterilisasi media pada autoclave pada suhu $121^{\circ} \mathrm{C}$ selama 15 menit, tunggu hingga media hangat. Kemudian buat membuat pengenceran susu dengan perbandingan 1:9 $(1 \mathrm{ml}$ susu dengan $9 \mathrm{ml}$ Buffer Peptone Water) hingga pengenceran $10^{-5}$. Tuang masing-masing hasil pengenceran sebanyak $1 \mathrm{ml}$ pada cawan Petri kemudian tambahkan media yang telah hangat sebanyak 12-15 ml kemudian campurkan dengan mengocoknya di dekat Bunsen seperti membentuk angka 8. Selanjutnya biarkan media memadat dan masukkan ke dalam incubator dengan posisi cawan terbalik, tunggu hingga 48 jam dan hitung total bakteri yang tumbuh menggunakan colony counter. Hasil yang didapat dicatat kemudian dilakukan penjumlahan dan rata-rata dari total sampel yang didapat.

\section{HASIL DAN PEMBAHASAN}

Penghitungan jumlah koloni bakteri dilakukan menggunakan colony counter. Hasil penghitungan rata-rata jumlah cemaran bakteri susu segar kambing jawa randu di Kecamatan 
Tabel 1. Hasil perhitungan cemaran bakteri pada susu segar kambing jawa randu

\begin{tabular}{ccccccc}
\hline \multirow{2}{*}{ Peternakan } & \multicolumn{5}{c}{ Sampel (CFU/ml) } & Rata-rata \\
\cline { 2 - 6 } & $\mathbf{1}$ & $\mathbf{2}$ & $\mathbf{3}$ & $\mathbf{4}$ & $\mathbf{5}$ & (CFU/ml) \\
\hline A & $3.8 \times 10^{5}$ & $1.6 \times 10^{5}$ & $1.6 \times 10^{5}$ & $3.7 \times 10^{5}$ & $1.6 \times 10^{5}$ & $2.5 \times 10^{5}$ \\
$\mathrm{~B}$ & $1.6 \times 10^{5}$ & $1.8 \times 10^{5}$ & $2.6 \times 10^{5}$ & $3.4 \times 10^{5}$ & $1.7 \times 10^{5}$ & $2.2 \times 10^{5}$ \\
$\mathrm{C}$ & $3.3 \times 10^{5}$ & $4.5 \times 10^{5}$ & TBUD & TBUD & $1.7 \times 10^{6}$ & $8.3 \times 10^{5}$ \\
$\mathrm{D}$ & $1.2 \times 10^{6}$ & $1.2 \times 10^{6}$ & TBUD & $1.7 \times 10^{5}$ & $8.2 \times 10^{5}$ & $8.5 \times 10^{5}$ \\
\hline
\end{tabular}

Keterangan TBUD: Terlalu Banyak Untuk Dihitung

Siliragung Kabupaten Banyuwangi dapat dilihat pada Tabel 1.

Penelitian jumlah cemaran bakteri pada susu segar kambing Jawa Randu di Siliragung, Banyuwangi dilakukan menggunakan uji TPC. Hasil yang diperoleh menunjukkan perbedaan nilai rata-rata cemaran bakteri pada masingmasing peternakan. peternakan A $2.5 \times 10^{5}$ $\mathrm{CFU} / \mathrm{ml}$, peternakan B $2.2 \times 10^{5} \mathrm{CFU} / \mathrm{ml}$, peternakan $\mathrm{C} 8.3 \times 10^{5} \mathrm{CFU} / \mathrm{ml}$, dan peternakan D $8.5 \times 10^{5} \mathrm{CFU} / \mathrm{ml}$,ada juga sampel susu segar yang menunjukan nilai Terlalu Banyak Untuk Dihitung (TBUD), artinya sampel tersebut mengandung terlalu banyak bakteri sehingga sulit untuk dihitung.

Susu kambing di Indonesia belum ditentukan standar batas maksimal cemaran bakteri, namun hasil dari pemeriksaan susu segar kambing di Kecamatan Siliragung Kabupaten Banyuwangi saat dibandingkan dengan Thai Agricultural Standar (2008), cemaran bakteri yang ada di semua sampel melebihi batas maksimum TPC $2 \times 10^{5} \mathrm{CFU} / \mathrm{ml}$.

Perbedaan nilai jumlah cemaran bakteri yang terdapat pada beberapa peternakan kambing perah di Siliragung, Banyuwangi menunjukkan bahwa tingkat higiene dan sanitasi pada proses pemerahan dan managemen pemeliharaan ternak juga berbeda. Menurut Cahyono et al., (2013) perbedaan jumlah TPC kemungkinan disebabkan karena perbedaan dalam sanitasi kandang, peralatan dan pemerahan. Pemeliharaan ternak dan penanganan baik saat pemerahan dan pasca pemerahan merupakan faktor penting untuk menghasilkan susu kambing yang aman, sehat, utuh dan halal. Namun, pada keempat peternakan masih belum melakukan penanganan yang baik pada saat pemerahan dan pasca pemerahan.
Pemerahan di 4 peternakan Siliragung, Banyuwangi biasanya dilakukan pada pagi hari mulai pukul 05.00 dan ada yang mulai pukul 09.00. Waktu pemerahan tidak menentu tergantung kesibukan dari masing-masing peternak setiap harinya. Pemerahan dilakukan didalam kandang kambing. Temperatur dan kelembaban dapat mempengaruhi total bakteri susu karena pada pagi hari umumnya suhu lebih rendah dengan kelembaban yang lebih tinggi dibanding sore hari. Kondisi tersebut dapat membantu pertumbuhan bakteri. Hal ini sesuai dengan Gaman dan Sherrington (1994) menjelaskan bahwa yang mempengaruhi pertumbuhan bakteri adalah waktu, kelembaban, dan suhu.

Susu merupakan produk pangan asal hewan yang mata rantai produksinya harus sesuai dengan Pasal 3 Peraturan Pemerintah Republik Indonesia Nomor 95 Tahun 2012 tentang Kesehatan Masyarakat Veteriner dan Kesejahteraan Hewan, meliputi penjaminan higiene dan sanitasi, penjaminan produk hewan, dan pengendalian dan penanggulangan zoonosis.

Higiene merupakan seluruh tindakan yang dilakukan untuk meningkatkan kesehatan. Sanitasi adalah usaha pencegahan penyakit dengan menghilangkan atau mengatur faktorfaktor lingkungan yang berkaitan dengan rantai perpindahan penyakit tersebut. Cara yang baik untuk rantai produksi hewan perah dilakukan dengan penjaminan kebersihan kandang, peralatan dan lingkungannya, penjaminan kesehatan dan kebersihan hewan terutama ambing, penjaminan kesehatan dan kebersihan personel, pemisahan hewan baru dari hewan lama dan hewan sakit dari hewan sehat, pencegahan bersarangnya hewan pengganggu, pemberian obat hewan di bawah pengawasan Dokter Hewan, pemberian pakan yang aman dan 
sesuai dengan kebutuhan fisiologis hewan (PP RI No. 95 Tahun 2012).

Pemerahan dilakukan menggunakan tangan dengan metode lima jari. Peralatan yang digunakan masih sederhana berupa botol yang ada, bahkan menggunakan botol bekas perahan susu yang sebelumnya telah dipakai, dipakai kembali untuk pemerahan. Kebersihan botol tidak terlalu diperhatikan oleh peternak. Sebelum melakukan pemerahan ambing dicuci terlebih dahulu dengan air hangat dan dikeringkan dengan menggunakan kain lap. Setelah itu kambing diperah, kemudian ambing dibersihkan kembali dengan air hangat.

Setelah pemerahan, susu yang ditampung pada botol tersebut dikumpulkan pada Milk can. Air yang digunakan untuk membersihkan peralatan, tangan pemerah, dan ambing juga mempengaruhi tingkat pencemaran pada susu, sehingga perlu dijaga dari kontaminasi feses (Nanu et al., 2007). Perkins et al., (2009) menambahkan bahwa kualitas air yang digunakan untuk membersihkan peralatan memiliki pengaruh yang besar terhadap kualitas susu segar yang dihasilkan. Hal ini memungkinkan tingginya cemaran pada susu yang dihasilkan suatu peternakan disebabkan oleh sanitasi kandang dan higiene pemerahan yang buruk (Fikri et al., 2017).

Tingginya kandungan total bakteri pada susu segar yang diperoleh dari peternakan di Kecamatan Siliragung Kabupaten Banyuwangi kemungkinan disebabkan oleh adanya kontaminasi yang bersumber dari udara, tubuh pemerah dan sanitasi peralatan pemerah yang masih sangat minim. Uji TPC dapat memberikan gambaran umum tentang kondisi mikrobiologis pada susu segar kambing (Walstra et al., 2006).

Sanitasi kandang beraneka ragam, ada yang dilakukan setiap hari ada juga yang tergantung waktu luang dari peternak tersebut. Peternak rata-rata membersihkan kandang sehari sekali. Sanitasi kandang yang dilakukan hanya menyapu lantai kandang bagian dalam, namun banyak kotoran berserakan di sekitar kandang. Lalu kotoran yang jatuh dipindahkan pada satu tempat yang masih dalam area kandang untuk dijadikan pupuk. Hal ini sesuai dengan pendapat
Saksono dan Saksono (1986), bahwa bakteri dalam air susu akan meningkat jumlahnya disebabkan oleh kandang yang kurang bersih (Fikri et al., 2018; Pradika et al., 2019).

Menurut Kelly et al., (2009), pertumbuhan bakteri dapat ditekan dengan good higiene dan manajemen peternakan yang baik. Salah satu faktor yang penting dalam hygiene dan sanitasi adaah kebersihan ambing dan puting (Cempirkova, 2006). Susu merupakan media yang sangat baik untuk pertubuhan, perkembangan dan penyebaran bakteri yang berbahaya untuk kesehatan manusia sebagai konsumen apabila proses penanganannya tidak memperhatikan aspek kebersihan (Balia dkk., 2008). Menurut Rombaut (2005), pencemaran pada susu terjadi sejak proses pemerahan, dari berbagai sumber seperti kulit, ambing, puting, air, tanah, debu, manusia, peralatan, dan udara. Elmoslemenya et al., (2010) menambahkan bahwa kontaminasi mikroorganisme pada susu bisa terjadi di wadah penampung melalui tiga sumber utama, yaitu kontaminasi bakteri dari permukaan luar ambing dan puting, permukaan peralatan susu, dan dari mikroorganisme penyebab mastitis di dalam ambing. Artinya bahwa jumlah bakteri pada susu dimulai dari peternakan dan dipengaruhi oleh banyak prosedur dan tata laksana pada kandang.

Menurut Buckle et al., (1987) bakteri yang dapat mencemari susu terdiri atas dua golongan, yaitu bakteri patogen dan bakteri pembusuk. Kedua golongan bakteri tersebut dapat menyebabkan penyakit pada manusia, seperti Tuberculosis, Brucellosis, diare dan demam tipoid. Bakteri lain yang terdapat di dalam susu yang dapat menyebabkan penyakit adalah Salmonella, Shigella, Bacillus cereus, dan S. aureus. Oleh karena itu, sebelum mengonsumsi susu perlu memperhatikan terlebih dahulu kondisi susu tersebut.

\section{KESIMPULAN}

Dari hasil penelitian dapat disimpulkan bahwa jumlah total bakteri pada susu segar kambing Jawa Randu di Kecamatan Siliragung Kabupaten Banyuwangi belum sesuai standard. 


\section{UCAPAN TERIMA KASIH}

Peneliti mengucapkan terimakasih kepada tenaga pendidikan Pengujian Mutu dan Pengembangan Produk Kelautan dan Perikanan atas bantuan dalam proses penelitian.

\section{DAFTAR PUSTAKA}

Badan Standarisasi Nasional. SNI 2332.32015.Cara Uji Mikrobiologi Bagian3 Penentuan Angka Lempeng Total (ALT) pada Produk Perikanan Jakarta.

Balia, R.L., Harlia, E., Suryanto, D. 2008. Jumlah Bakteri Total dan Koliform pada Susu Segar Peternakan Sapi Perah Rakyat dan Susu Pasteurisasi Tanpa Kemasan di Pedagang Kaki Lima. [Skripsi]. Fakultas Peternakan Universitas Padjadjaran, Bandung.

Buckle, K.A., Edwards, R.A., Fleet, G.H., Wotton, M. 1987. Ilmu Pangan. Penerjemah Hari Purnomo dan Adiono. Universitas Indonesia Press. Jakarta.

Cahyono, D., Padaga, M.C., Sawitri, M.E. 2013. Kajian Kualitas Mikrobiologis Total Plate Count (TPC), Enterobacteriaceae dan Staphylococcus aureus Susu Sapi Segar di Kecamatan Krucil Kabupaten probolinggo. Jurnal Ilmu dan Teknologi Hasil Ternak, 8(1), 1-8.

Ceballos, L.S., Morales, E.R., de la Torre Adarve, G., Castro, J.D., Martínez, L.P., Sampelayo, M.R.S. 2009. Composition of Goat and Cow Milk Produced Under Similar Conditions and Analyzed by Identical Methodology. J. Food Composit. Analys., 22(4), 322-329.

Cempirkova, R. 2006 Factors Negatively Influencing Microbial Contamination Of Milk. J. Agric. Trop. Et Subtrop. 39, 220221.
Chotiah, S. 2008. Diare pada Anak Sapi: Agen Penyebab, Diagnosa dan Penanggulangan. Prosiding Prospek Industri Sapi Perah Menuju Perdagangan Bebas 2020, Pusat Penelitian dan Pengembangan Peternakan, Badan Penelitian dan Pengembangan Pertanian, Departemen Pertanian . Jakarta, 21 April 2008.

Elmoslemanya, A.M., Keefe, G.P., Dohoo, I.R., Wichtel, J.J., Stryhn, H., Dingwell, R.T. 2010. The Association Between Bulk Tank Milk Analysis for Raw Milk Quality and on-Farm Management Practices. Prev. Vet. Med., 95, 32-40.

Fikri, F., Hamid, I.S., Purnama, M.T.E. 2017. Uji organoleptis, $\mathrm{pH}$, uji eber dan cemaran bakteri pada karkas yang diisolasi dari kios di Banyuwangi. Jurnal Medik Veteriner, 1(1), 23-27.

Fikri, F., Purnama, M.T.E., Saputro, A.L., Hamid, I.S. 2018. Identifikasi Escherichia coli dan Salmonella spp pada Karkas Sapi di Rumah Potong Hewan di Banyuwangi dan Resistensi Terhadap Antibiotika. Jurnal Sain Veteriner, 36(1), 123-128.

Gaman, P.M., Sherrington, K.B. 1992. Ilmu Pangan, Pengantar Ilmu Pangan, Nutrisi, dan Mikrobiologi. Gardjito M, penerjemah; Kasmidjo RB editor. Yogyakarta: Gadjah Mada Univ Pr. Terjemahan dari: The Science of Food, an Introduction to Food Science, Nutrition and Microbiology.

Griffiths, M.W. 2000. Milk and Unfermented Milk Product. Di dalam: Lund BM, BairdParker TC, Gould GW, editor. The Microbiologycal Safety and Quality of Food. Vol. 1: 508-514 Aspen Pub.: Maryland (US).

Hasim \& E. Martindah. 2012. Perbandingan Susu Sapi dengan Susu Kedelai : Tinjauan Kandungan dan Biokimia Absorbsi. Pusat 
Penelitian dan Pengembangan Peternakan. Badan Penelitian dan Pengembangan Pertanian. Departemen Pertanian, Bogor. Semiloka Nasional Prospek Industri Sapi Perah Menuju Perdagangan Bebas 2020: 272-278.

Kelly, P.T., O'Sullivan, K., Berry, D.P., More, S.J., Meaney, W.J., O'Callaghan, E.J., O'Brien, B. 2009. Farm Management Factors Associated With Bulk Tank Total Bacterial Count in Irish Dairy Herds During 2006/07. J. Vet. Irish, 62, 36-42.

Mennane, Z., Ouhssine, M.K., Elyachioui, M. 2007. Hygienic Quality of Raw Cow's Milk Feeding from Domestic Waste in Two Regions in Morocco. Int. J. Agric. Biol., 9, 46-47.

Nanu, E., Latha, C., Sunil, B., Prejit Thomas, M., Venon, K.V. 2007. Quality Assurance and Public Health Safety of Raw Milk at The Production Point. Am. J. Food Technol., 2(3), 145-152.

Peraturan Pemerintah. Tahun 2012 Tentang Kesehatan Masyarakat Veteriner dan Kesejahteraan Hewan. Peraturan Pemerintah Republik Indonesia Nomor 95.

Perkins, N.R., Kelton, D.F., Hand, K.J., MacNaughton, G., Berke, O., Leslie, K.E. 2009. An Analysis of The Relationship
Between Bulk Tank Milk Quality and Wash Water Quality on Dairy Farms in Ontario, Canada. J. Dairy Sci., 92(8), 3714-3722.

Pradika, A.Y., Chusniati, S., Purnama, M.T.E., Effendi, M.H., Yudhana, A., Wibawati, P. A. 2019. Uji Total Escherichia coli pada Susu Sapi Segar di Koperasi Peternak Sapi Perah (KPSP) Karyo Ngremboko Kecamatan Purwoharjo Kabupaten Banyuwangi. Jurnal Medik Veteriner, 2(1), 1-6.

Saksono, L., Saksono, I. 1986. Pengantar Sanitasi Makanan, Bandung: Alumni Bandung.

Thai Agricultural Standard. 2008. Raw goat milk. National Bureau of Agricultural Commodity and Food Standards. Ministry of Agriculture and Cooperatives, Thailand.

Roumbaut, R. 2005. Diary Microbiology and Starter Cultures.Laboratory of Food Technology and Engineering. Gent University Press. Belgium.

Walstra P., Wouters, J.T.M., Geurts, T.J. 2006. Dairy Science and Technology. 2nd Ed. CRC Press Taylor \& Francis Group. New York. pp: 197-204.

Waluyo, L. 2004. Mikrobiologi Umum. UMM Press, Malang, Hal: 9-19. 